\title{
Diagensis and Factor Analysis of Sandstones of Injana Formation in Selected Sections Northern Iraq
}

\author{
Thamer A. Aghwan \\ Department of Geology \\ College of Science \\ Mosul University
}

\author{
Nabil Y. Al-Banna \\ Dams and Water Resources \\ Research Center \\ Mosul University
}

\author{
Mohammed A. AL-Rashedi \\ Department of Soil and Water Sciences \\ College of Agriculture and Forestry \\ Mosul University
}

(Received 4/11/2007, Accepted 15/1/2008)

\begin{abstract}
Three sections of Injana Formation are studied in selected areas at Northern Iraq. Tewenty seven samples of sandstone are chosen for point counting and diagensis studies. The classification of these sandstone beds are feldspathic litharenite. A diagenetic study elucidates the presence of carbonate, iron oxide, clay and silicate cements, as well as compaction, replacement, recrystallization and alteration processes.

Factor analysis shows three main factors controlling the distribution of mineral and rock fragments in sandstones reflecting the type of source rocks and the maturity of the sandstone beds. The first is diagensis, the second is metamorphism of the source rocks, while the third factor is the mechanical erosion of the source rocks. The study of minerals and factor analysis indicate an acidic igneous rocks affected by differential metamorphism of the source rocks with sedimentary rock (carbonate and clastic) and immature texture of sandstone rocks.

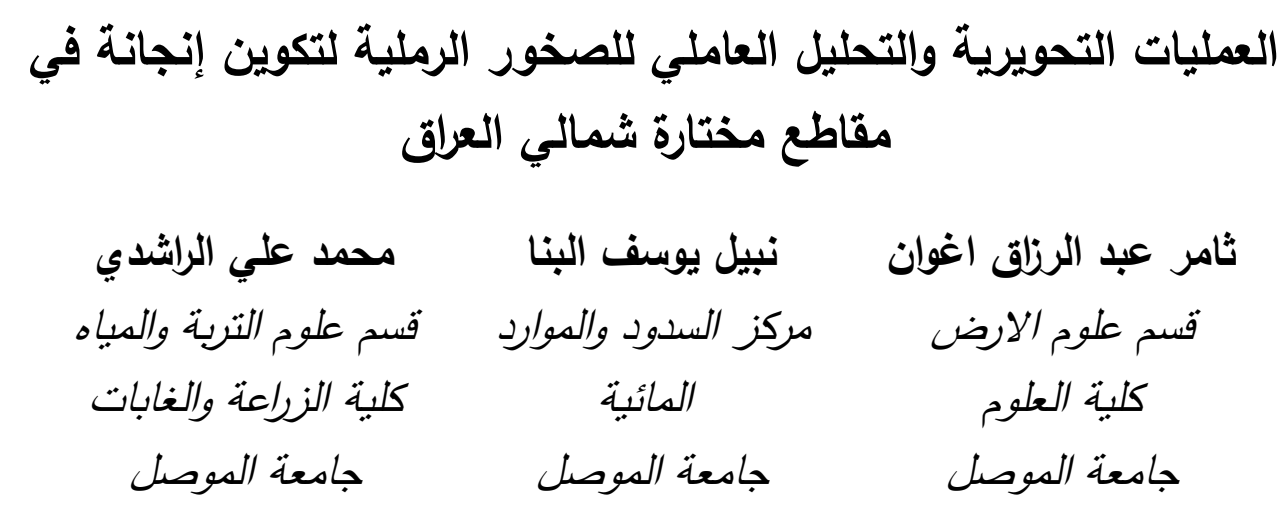

الملخص

درست ثلاثة مقاطع صخرية لتكوين إنجانة في مناطق مختارة من شمال العراق، تم اختيار (rV) أنموذج من الصخور الرملية للدراسة، أظهرت الدراسة التصنيفية للصخور الرملية لمقاطع الدراسة أنها تقع
\end{abstract}


ضمن حقل (Feldspathic Litharenite). أنشارت دراسة العمليات التحويرية إلى تواجد السمنت الكاربوناتي والطيني واكاسيد الحديد والسلكي، فضلاً عن عمليات الانضغاط والإحلال وإعادة التبلور والتغير. أوضح التحليل ألعاملي (Factor analysis) لنماذج مقاطع الدراسة وجود ثناثة عوامل رئيسة تسبطر على توزيع المعادن والفتات الصخري في الصخور الرملية والتي تعكس أنواع الصخور المصدرية ودرجة نضوج الصخور الرملية وهي عامل العمليات التحويرية وعامل التحول لصخور المصدر وعامل التعرية الميكانيكية للصخور المصدرية. تشير الدراسات المعدنية والتحليل ألعاملي للصخور الرملية إلى أن الصخور المصدرية لتكوين إنجانة هي صخور نارية حامضية متعرضة لعملية تحول متباينة الثدة يرافقها صخور

$$
\text { رسوبية (كاربوناتية وفتاتية )، وان نسيج الصخور الرملية للتكوين غير ناضج. }
$$

\section{INTRODUCTION}

Sandstone beds of Injana Formation (Late Miocene) (Bellen et al.,1959) were studied in three sections, northern Iraq. These sections were chosen with total number of 27 samples, they are taken from : Al-Khazer area at the right bank of Al-Khazer river $\left(36^{\circ} 18^{\prime} 233^{\prime} ; 43^{\circ} 32^{\prime} 19^{\circ}\right)$, Bastora valley in the southern limb of Bermam anticline ( $36^{\circ} 19^{\prime} 47^{\circ} ; 44^{\circ} 11^{\prime} 25^{\circ}$ ) and Ain Sifni area in the southern limb of Sheikhan anticline $\left(36^{\circ} 41^{\prime} 54{ }^{\circ} ; 43^{\circ} 20^{\prime} 05^{\prime}\right.$ ) (Fig.-1). Their thicknesses ranging between 175 395 meters (Fig.-2). The studied area are located on the folded zone of Iraq (Buday and Jassim, 1987).

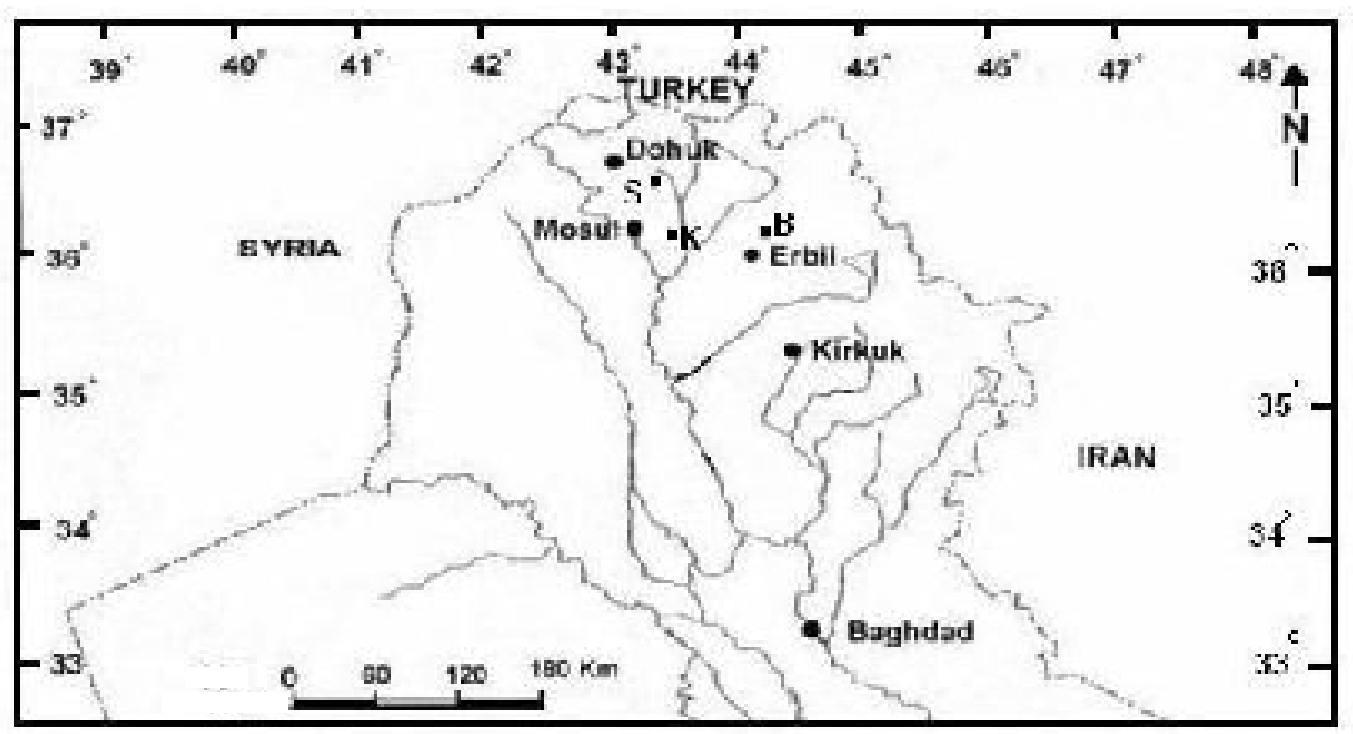

Fig. 1 : Location map of the studied sections (K, Al- Khazer section ; B, Bastora section; S, Ain Sifni section).

Injana Formation embraces sandstones, siltstones and mudstones; their facies relationship form fining upward cycles of meandering and braided river deposits (AlBanna, 1982). The lower boundary is confined and mentioned by last fossilefrous 
limestone or gypsum beds of Fat'ha Formation (Middle Miocene), while the upper boundary was gradational into Mukdadiya Formation ( Pliocene ) and detected by the first appearance of pebbly sandstone bed.

The objective of this research is to study the petrography, mineralogy, classification, and diagensis of sandstone and to find factors controlling the type of texture and source rocks by factor analysis of the studied sandstone samples.

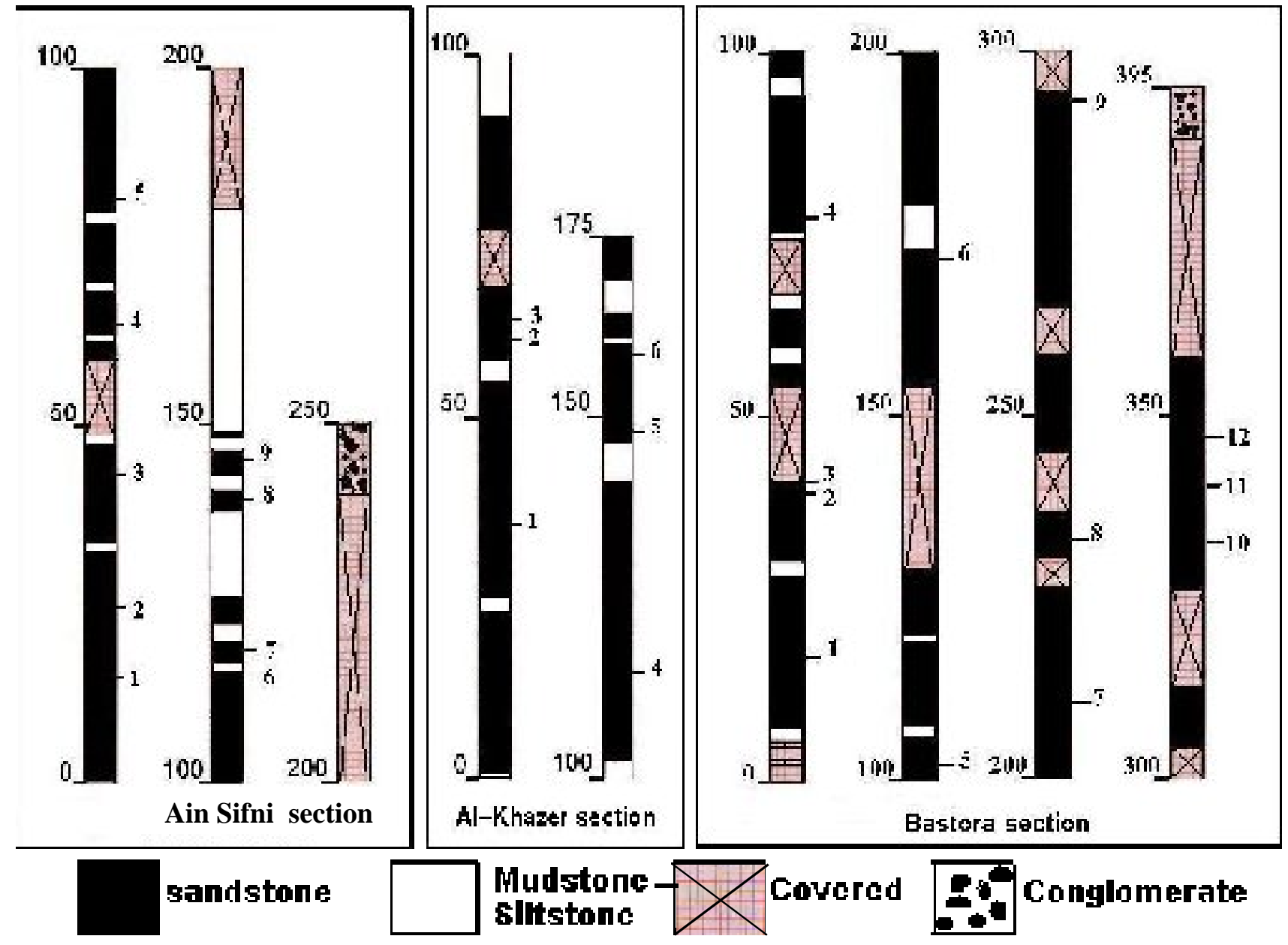

Fig. 2: Lithological sections of the studied areas.

\section{PETROGRAPHY}

In this study, modal analysis was carried out for twenty seven samples by point counting of an average of 300 points per thin section at a spacing of the largest grain size using the Gazzi-Dickinson method (Ingersoll et al., 1984).

The sandstone of Injana Formation consists of quartz (mono and polycrystalline), in which monocrystalline has a higher percentage than polycrystalline. Monocrystalline quartz is characterized by fine-coarse size, equigranular - elongated shape, with subhedral - anhedral crystals, angular - subrounded grains and parallel (non undulated) to wavy (undulated) extinction with inclusions of zircon, rutile and iron oxide which indicate a metamorphic and igneous source rocks (Folk, 1974). Polycrystalline quartz consists of 2-5 crystals with different size and curvature and suture contacts are recorded 
between crystals. The crystals show wavy extinction. All these properties point to a metamorphic origin of polycrystalline quartz (Folk, 1974).

The percentage of $\mathrm{K}$ and $\mathrm{Na}$ - feldspar representing the second degree of the total content of the studied sandstone, they are subangular - rounded grains, parallel extinction and some crystals of orthoclase and plagioclase were altered partly or completely to clay minerals.

Rock fragments are represented by sedimentary (carbonate, clastic and chert), igneous and metamorphic rocks (Table - 1).

Table 1 : Modal analysis of the various petrographic constituents of the studied sections.

\begin{tabular}{|c|c|c|c|c|c|c|c|c|c|c|c|c|c|c|c|c|}
\hline 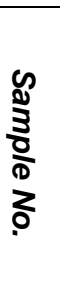 & 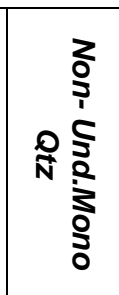 & 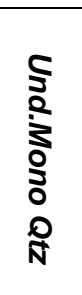 & 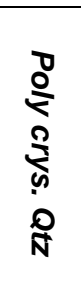 & $\frac{\rho}{\stackrel{\rho}{\$}}$ & 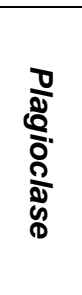 & $\begin{array}{l}\frac{\pi}{\pi} \\
\frac{1}{n}\end{array}$ & 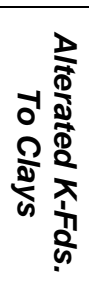 & $\begin{array}{l}8 \\
0 \\
0 \\
\vdots \\
0 \\
0 \\
0 \\
\pi\end{array}$ & 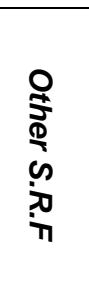 & 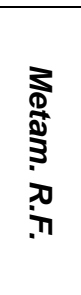 & 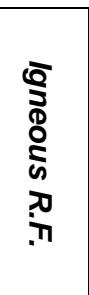 & 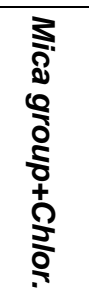 & 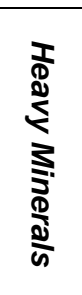 & 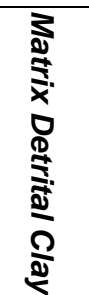 & 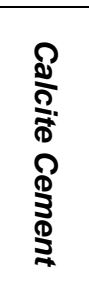 & 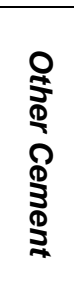 \\
\hline \multicolumn{17}{|c|}{ BASTORA } \\
\hline $\begin{array}{l}1 \\
2\end{array}$ & $\begin{array}{l}12 \\
16\end{array}$ & $\begin{array}{c}6 \\
5.33\end{array}$ & $\begin{array}{c}4 \\
5.33\end{array}$ & $\begin{array}{c}11.67 \\
10\end{array}$ & 4 & 5.33 & $\begin{array}{l}6 \\
6\end{array}$ & $\begin{array}{l}15.33 \\
18.67\end{array}$ & $\begin{array}{c}10 \\
1.33\end{array}$ & $\begin{array}{c}1 \\
1.33\end{array}$ & $\begin{array}{l}1.67 \\
0.67\end{array}$ & $\begin{array}{l}1 \\
4\end{array}$ & $\begin{array}{l}2 \\
2\end{array}$ & $\begin{array}{c}8.33 \\
0\end{array}$ & $\begin{array}{c}9 \\
20\end{array}$ & $\begin{array}{c}1.67 \\
0\end{array}$ \\
\hline 3 & 14 & 5 & 7 & 9 & 4 & 9 & 4 & 16.67 & 5 & 2 & 1 & 3.33 & 4 & 1 & 14 & 1 \\
\hline 4 & 12 & 5 & 8.67 & 11 & 1.67 & 4.33 & 8.33 & 12.33 & 9.67 & 2 & 0 & 4.33 & 2.33 & 8.67 & 8 & 2 \\
\hline 5 & 17 & 4 & 5 & 8 & 2.33 & 6 & 9.33 & 15 & 7 & 3 & 1 & 3 & 1 & 6 & 10 & 2.33 \\
\hline 6 & 13.33 & 3.33 & 5 & 10.33 & 3 & 5 & 8 & 10 & 14 & 0 & 0 & 5.33 & 3 & 8.67 & 5 & 6 \\
\hline 7 & 14.67 & 2.67 & 6 & 6.667 & 2.33 & 7 & 6 & 9 & 16.7 & 4 & 1.67 & 4 & 2.67 & 8 & 7 & 1.67 \\
\hline 8 & 19 & 8 & 3 & 7 & 2 & 5 & 3 & 23 & 4 & 1 & 0 & 2 & 1 & 1 & 19 & 2 \\
\hline 9 & 13 & 4 & 2 & 10 & 1 & 8 & 10 & 17 & 5 & 1 & 1 & 3 & 4 & 2 & 17 & 2 \\
\hline 10 & 15.67 & 5 & 4 & 12 & 2.67 & 6 & 9 & 21 & 7 & 0 & 0 & 2 & 1.67 & 0 & 14 & 0 \\
\hline 11 & 20 & 3 & 5 & 7 & 1.67 & 5 & 6.67 & 17 & 9 & 2 & 0.67 & 4 & 3.33 & 2.67 & 12 & 1 \\
\hline 12 & 19 & 3 & 6 & 7 & 3 & 6.67 & 7 & 18.67 & 6 & 4 & 0 & 3.67 & 2 & 4 & 10 & 0 \\
\hline \multicolumn{17}{|c|}{ AL-KHAZER } \\
\hline 2 & 16 & 6.66 & 4 & 7 & 4 & 6 & 7.33 & 18.33 & 8.33 & 0 & 0.66 & 6 & 2.33 & 0 & 12 & 1.33 \\
\hline 3 & 18 & 5.33 & 7 & 5 & 3 & 10 & 6 & 16 & 4.66 & 3 & 0 & 4 & 1 & 0 & 15 & 2 \\
\hline 4 & 15 & 4 & 5 & 7 & 3.33 & 8 & 7 & 13 & 5 & 4.66 & 4 & 3 & 2 & 0 & 18 & 1 \\
\hline 5 & 15 & 6 & 6 & 10 & 5 & 7 & 5 & 10 & 7 & 3 & 2 & 3 & 1 & 3 & 14 & 3 \\
\hline \multirow{2}{*}{\multicolumn{17}{|c|}{ AIN SiFNI }} \\
\hline & & & & & & & & & & & & & & & & \\
\hline 1 & 18 & 4 & 6 & 12 & 2.67 & 4 & 5 & 16 & 4 & 3 & 0.67 & 3.33 & 1.67 & 6 & 11 & 2.67 \\
\hline 2 & 16 & 7 & 5 & 10 & 1.67 & 6 & 8 & 21 & 2.3 & 1 & 0 & 2 & 3 & 2 & 14 & 1 \\
\hline 3 & 21 & 5 & 3.67 & 13 & 1.67 & 4 & 6 & 17.33 & 5 & 2.33 & 2 & 3.33 & 2.33 & 4.33 & 9 & 0 \\
\hline 4 & 13 & 6 & 5 & 9 & 4 & 7 & 9 & 15 & 7 & 4 & 1 & 5 & 2 & 2 & 9.67 & 1.33 \\
\hline 5 & 15 & 3.33 & 3 & 7 & 3 & 9 & 7 & 22.33 & 4 & 2 & 1.67 & 4 & 3.67 & 1 & 12 & 2 \\
\hline 6 & 14 & 4 & 5 & 8.33 & 5 & 6.7 & 9.33 & 13.33 & 6.7 & 3.67 & 2 & 4 & 2 & 5 & 10 & 1 \\
\hline 7 & 22 & 5 & 8 & 5 & 2 & 5 & 7 & 16.33 & 5 & 2 & 1 & 6 & 2.67 & 0 & 13 & 0 \\
\hline 8 & 17 & 7 & 5 & 11 & 4 & 7.7 & 7.67 & 17.33 & 10 & 3 & 0 & 2.33 & 2 & 4 & 8 & 4 \\
\hline 9 & 14 & 8 & 6 & 9 & 1.33 & 3 & 4.67 & 15 & 13 & 2.33 & 1 & 3.33 & 3.33 & 7 & 6 & 3 \\
\hline
\end{tabular}

The matrix consists of silt grains, clay grains and micritic grains that filled the intraparticle vugs. The main cement is spary calcite found around the grains or filling 
interpartical vugs. Iron oxide, clay and silicate cement are also recorded with low percentage.

According to McBride (1963) (Fig.-3) the sandstones of the Injana Formation are on the feldspathic litharenite field. The modal analysis data have been plotted on the ternary diagram of Dickinson et al. (1983). In this diagram, the studied sandstones are situated on recycled orogen - dissected arc (Fig.- 4).

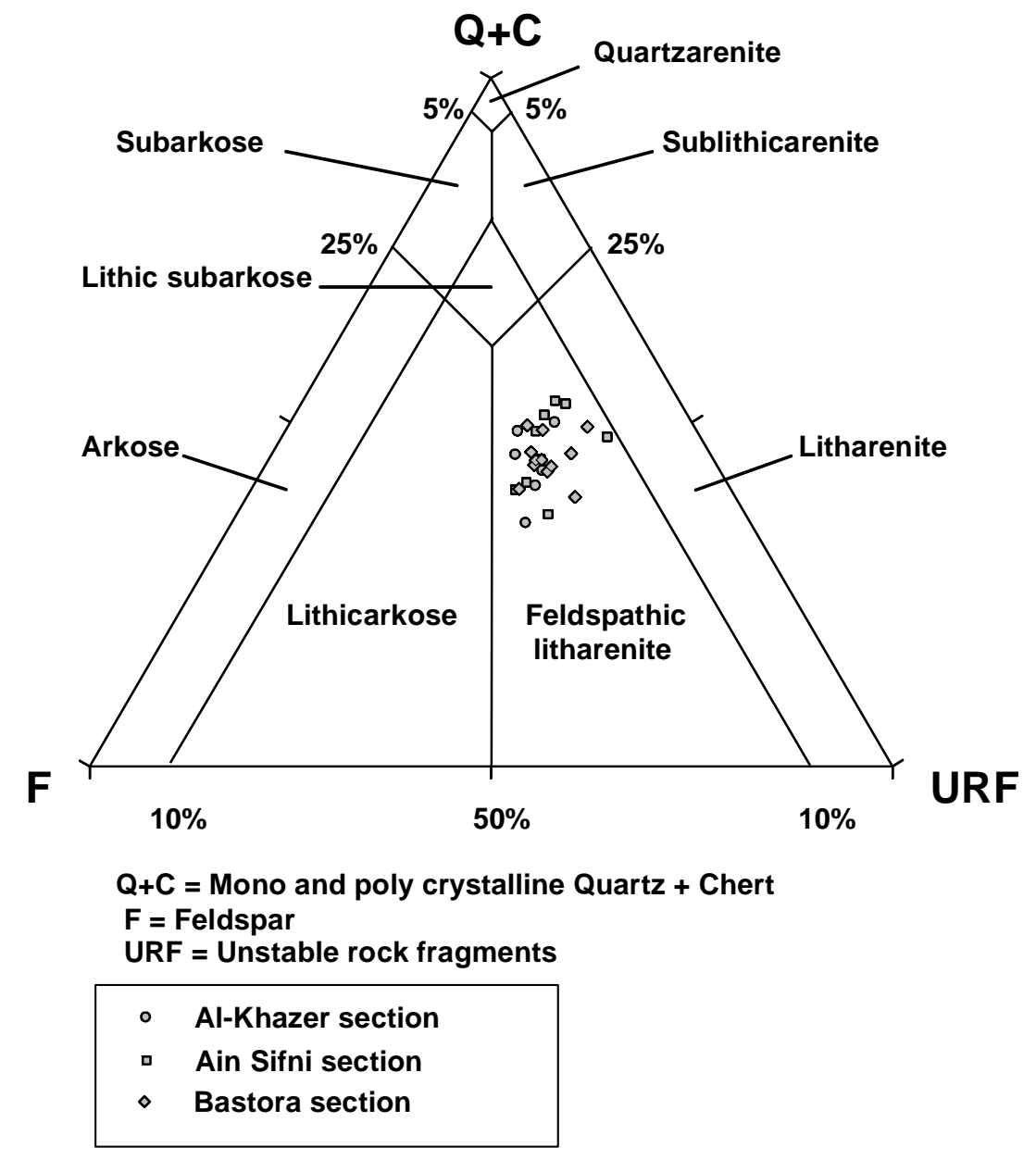

Fig.3: Position of Injana Formation sandstones on the classification of McBride (1963).

\section{DIAGENESIS}

A wide variety of diagenetic processes have been noticed in the sandstones of the Injana Formation. These processes includes compaction, cementation, recrystallization and alteration of mineral grains.

Compaction: The point and linear contact of the grain and the degree of curvature and distortion of mica grains are clear evidence of the limited effect of compaction on sandstone samples (plate 1- A, B,) (Rossi et al., 2001) .

Cementation: Different types of cement are recorded in the sandstone of the Injana Formation; carbonate cement is the main dominant; it is blocky spary calcite forming poikilotopic texture with surrounding finer clastic grains (plate 1-C). Sometimes pervasive cement found as floated grains in the matrix. The above mentioned types of cement occurred before the completion of compaction (Adams,1964). 


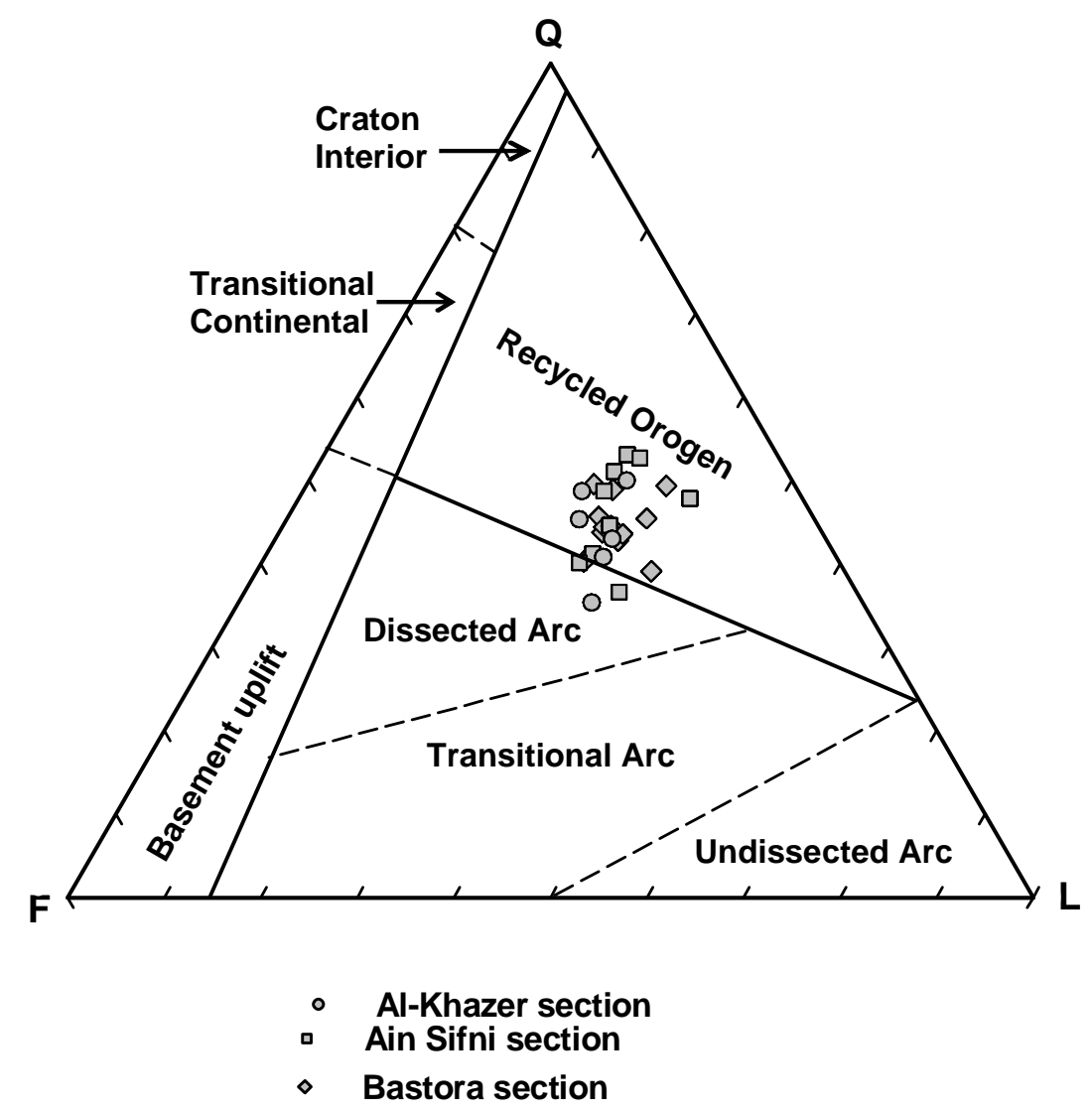

Fig. 4: Position of Injana Formation sandstones, on the classification of Dickinson et al., (1983) of tectonic fields.

Thin film of clay and iron oxide cement is found around the grains with brown to red color( plate 1-D). The clay cement was formed by filtration process in early diagenesis stage (De Ros et al., 1994), while iron oxide cement was resulted from the weathering process of the source rocks bearing iron (Dypvik and Nilson, 2002). A low amount of silicate cement is found as a thin film coating quartz grains as quartz overgrowth ( plate 1-E).

Replacement: Quartz and feldspar grains are partly or completely replaced by calcite cement. The affected mineral edges were eroded (plate 1-F). This process usually takes place in the middle stage of diagentic processes (McBride et al., 2003).

Alteration: This process is represented by the partly or complete alteration of feldspar to clay minerals due to the activity of solution along the cleavage planes (Plate 1-G); also the presence of vugs in K-feldspar is an indication of pseudomorphs (Morad et al., 1989).

Recrystallization: Some micrite grains are recrystallized to microspare cement but this process is of local occurrence ( plate 1-H). 


\section{Factor analysis:}

There are many statistical analyses methods for the study of cases and variables in various field of science. One of these methods is the factor analysis and its application in geology. Factor analysis of carbonates, muds and marls with their mineral and chemical contents as variables are used to find factors affecting the mineral and chemical distribution in the rock (Aswad et al., 2005).

Tectonic history of accretionary complex has been studied using sandstone framework complex, mud rock and geochemistry in factor analysis to discover the internal relation between geochemical variables withen the sediment.(Joo et al., 2007).

This study has adopted the modal analysis results from point counting of sandstones of three lithological sections (Table -1) in factor analysis, which was applied to reveal the internal relations between mineral, cement and rock fragment variables in the studied rocks. The resultant factor was found to control the texture and source rock condition of the sandstone.

Principle component analysis was used for factor extraction and iterative estimation for communalities proceeded until they are converged on the definite state. Results factor were rotated by the varimax method with normalization. The resultant three factors explain a range $(16.505-29.748)$ of the total variances (Table-2,3 and 4).

\section{Factor 1:}

This factor shows a high negative factor loading for calcite cement in sections (A1Khazer and Ain Sifni) while a positive factor loading of the same variable in Bastora section. A high positive factor loading is shown for matrix detrital clay and clastic rock fragments in the three studied sections (Table-2,3 and 4). These variables are responsible for the degree of diagensis during and after the deposition of sandstone whereas the positive and negative charges probably relate the time of diagensis (early or late ), accordingly, factor -1 can be named as factor of diagensis .

\section{Factor -2}

This factor displays a high positive factor loading for igneous and metamorphic quartz in Al-Khazer section while positive factor loading is detected for plagioclase and metamorphic rock fragments in Ain Sifni section and a high positive factor loading for chert in Bastora section.

A high negative factor loading is observed for igneous quartz in Bastora section and moderate negative value for igneous and metamorphic quartz in Ain Sifni section. Kfeldspar and plagioclase show a high negative factor loading in Al- Khazer section and a high positive factor loading in Ain Sifni section, while it is very low in Bastora section. A high factor loading is observed for metamorphic rock fragments in Ain sifni and Bastora sections (Table 2 and 4 ).

Generally, the high factor loading of the main variables in factor- 2 relates the degree of metamorphism of the source rocks. This result was detected from the factor 
loading of metamorphic quartz and their relation with the factor loading of plagioclase and $\mathrm{K}$-feldspar. A high factor loading of igneous and metamorphic quartz is correlated with a high negative value for plagioclase and $\mathrm{K}$ - feldspar in Al-Khazer section. Moderate factor loading of igneous and metamorphic quartz is correlated with high positive value of plagioclase and K- feldspar in Ain Sifni section. On the other hand, in Bastora section a low factor loading for metamorphic quartz and plagioclase and $\mathrm{K}$ feldspar are recorded. All these results, suggest a relation of these variables with metamorphism. Therefore we can name factor- 2 as factor of degree of metamorphism of the source rocks.

Table 2: Factor loading of variance of Ain Sifni section.

\begin{tabular}{|c|c|c|c|c|c|}
\hline \multicolumn{6}{|c|}{ Factor loadings (Varimax normalized), Ain Sifni section } \\
\hline NO. & Variance & F1 & F2 & F3 & Communality \\
\hline 1 & Non- Und.Mono Qtz & -.193528 & -.536601 & .333754 & 0.436785 \\
\hline 2 & $\begin{array}{l}\text { Und.Mono Qtz } \\
\text { Poly crys. Qtz }\end{array}$ & .375634 & -.475792 & -.097811 & 0.377045 \\
\hline 3 & Chert & .325728 & -.036039 & -.515156 & 0.372783 \\
\hline 4 & Plagioclase & .110674 & .967379 & .069683 & 0.952926 \\
\hline 5 & K-Fds & -.547948 & .734043 & -.156494 & 0.863556 \\
\hline 6 & Alterated K-Fds. & -.381850 & .712830 & .228522 & 0.706158 \\
\hline 7 & Carbon. S.R.F. & -.819513 & -.188400 & -.419622 & 0.883178 \\
\hline 8 & Other S.R.F & .800492 & -.006964 & -.189375 & 0.676698 \\
\hline 9 & Metam. R.F. & .592684 & .734897 & .236664 & 0.942957 \\
\hline 10 & Igneous R.F. & .115979 & .168019 & .639616 & 0.423356 \\
\hline 11 & Mica group+Chlor. & -.016232 & .091833 & .896231 & 0.803230 \\
\hline 12 & H.M. & -.171951 & -.675296 & -.092771 & 0.494198 \\
\hline 13 & Matrix Detrital Clay & .818859 & -.079472 & -.346801 & 0.797116 \\
\hline 14 & Calcite Cement & -.883152 & -.049399 & .205833 & 0.824760 \\
\hline 15 & Other Cements & .398549 & .198685 & -.757847 & 0.772649 \\
\hline \multicolumn{2}{|c|}{ Variance explained (\%) } & 27.0615 & 24.0995 & 17.9586 & \multirow{3}{*}{$\begin{array}{l}\text { Note; } \\
\text { Factor loading } \\
>0.5 \text { are marked } \\
\text { bold }\end{array}$} \\
\hline \multirow{2}{*}{\multicolumn{2}{|c|}{$\begin{array}{c}\begin{array}{c}\text { Cumulated Variance } \\
\text { explained } \%\end{array} \\
\text { Eigen values } \\
\end{array}$}} & 27.0615 & 51.1510 & 69,1096 & \\
\hline & & 4.0592 & 3.6149 & 2.6937 & \\
\hline
\end{tabular}

\section{Factor -3}

This factor has a high positive factor loading of igneous and / or metamorphic rock fragments in the studied sections. Also a high positive factor loading is recorded for Kfeldspar in Bastora section and mica group \& chlorite in Ain Sifni section, while there are a high negative factor loading of carbonate rock fragments and mica group \& chlorite in Al- Khazer section (Table-2,3 and 4).

As a matter of fact, the positive or negative value of the main variable relates the degree of mechanical erosion of the source rocks. Accordingly, this factor is named as factor of mechanical erosion.

Table 3: Factor loading of variance of Al-Khazer. 


\begin{tabular}{|c|c|c|c|c|c|}
\hline \multicolumn{6}{|c|}{ Factor loadings (Varimax normalized), Al - Khazer section } \\
\hline NO. & Variance & F1 & F2 & F3 & Communality \\
\hline 1 & Non- Und.Mono Qtz & .217379 & .970423 & -.019329 & 0.934465 \\
\hline 2 & $\begin{array}{l}\text { Und.Mono Qtz } \\
\text { Poly crys. Qtz }\end{array}$ & .247954 & .841631 & .066895 & 0.774249 \\
\hline 3 & Chert & .416120 & -.672383 & .454820 & 0.832115 \\
\hline 4 & Plagioclase & -.133294 & -.87840 & .032505 & 0.790410 \\
\hline 5 & K-Fds & -.959695 & -.67866 & .007038 & 0.921064 \\
\hline 6 & Alterated K-Fds. & -.045134 & -.722866 & -.611980 & 0.829091 \\
\hline 7 & Carbon. S.R.F. & -.164445 & -.501042 & -.845466 & 0.992898 \\
\hline 8 & Other S.R.F & .851025 & .342779 & -.089960 & 0.849833 \\
\hline 9 & Metam. R.F. & -.425698 & .026083 & .706683 & 0.748651 \\
\hline 10 & Igneous R.F. & .012447 & -.319457 & .718684 & 0.516661 \\
\hline 11 & Mica group+Chlor. & .401357 & -.030037 & -.888493 & 0.951409 \\
\hline 12 & H.M. & .751119 & .019443 & -.400097 & 0.724635 \\
\hline 13 & Matrix Detrital Clay & .814424 & .325090 & .078520 & 0.775135 \\
\hline 14 & Calcite Cement & -.699485 & .102755 & .522455 & 0.772797 \\
\hline 15 & Other Cements & -.492960 & -.056847 & .475513 & 0.472353 \\
\hline \multicolumn{2}{|c|}{ Variance explained (\%) } & 28.5081 & 26.6234 & 25.2062 & \multirow{3}{*}{$\begin{array}{l}\text { Note; } \\
\text { Factor loading }>0.5 \\
\text { are marked bold }\end{array}$} \\
\hline \multicolumn{2}{|c|}{$\begin{array}{c}\text { Cumulated Variance } \\
\text { explained (\%) }\end{array}$} & 28.5081 & 55.1315 & 80.3377 & \\
\hline \multicolumn{2}{|c|}{ Eigen values } & 4.2762 & 3.9935 & 3.7809 & \\
\hline
\end{tabular}

Table 4: Factor loading of variance of Bastora section.

\begin{tabular}{|c|c|c|c|c|c|}
\hline \multicolumn{6}{|c|}{ Factor loadings (Varimax normalized), Bastora section } \\
\hline NO. & Variance & F1 & F2 & F3 & Communality \\
\hline 1 & Non- Und.Mono Qtz & -.335495 & -.734323 & -.446933 & 0.864696 \\
\hline 2 & $\begin{array}{l}\text { Und.Mono Qtz } \\
\text { Poly crys. Qtz }\end{array}$ & -.043729 & .064588 & -.338155 & 0.120435 \\
\hline 3 & Chert & -.061074 & .951239 & .016028 & 0.908842 \\
\hline 4 & Plagioclase & -.242844 & .008970 & .160289 & 0.084746 \\
\hline 5 & $K-F d s$ & -.271397 & .029249 & .908066 & 0.899095 \\
\hline 6 & Alterated K-Fds. & .329370 & .412606 & -.052322 & 0.281465 \\
\hline 7 & Carbon. S.R.F. & -.911070 & -.060602 & -.323654 & 0.938473 \\
\hline 8 & Other S.R.F & .871334 & -.027183 & .213182 & 0.805408 \\
\hline 9 & Metam. R.F. & .236929 & -.820846 & .240326 & 0.769290 \\
\hline 10 & Igneous R.F. & .062593 & -.139488 & .868516 & 0.777076 \\
\hline 11 & Mica group+Chlor. & .602540 & -.146208 & -.239192 & 0.441644 \\
\hline 12 & H.M. & .144495 & .154839 & .533035 & 0.328980 \\
\hline 13 & Matrix Detrital Clay & .891483 & .075945 & .133804 & 0.812645 \\
\hline 14 & Calcite Cement & .893591 & .002918 & -.130710 & 0.815598 \\
\hline 15 & Other Cements & .690259 & .328101 & -.106697 & 0.595486 \\
\hline \multicolumn{2}{|c|}{ Variance explained (\%) } & 29.7485 & 16.5058 & 16.7824 & \multirow{3}{*}{$\begin{array}{l}\text { Note; } \\
\text { Factor loading } \\
>0.5 \text { are marked } \\
\text { bold }\end{array}$} \\
\hline \multicolumn{2}{|c|}{$\begin{array}{c}\text { Cumulated Variance } \\
\text { explained (\%) }\end{array}$} & 29.6485 & 46.2543 & 63.0367 & \\
\hline \multicolumn{2}{|c|}{ Eigen values } & 4.4622 & 2.4758 & 2.5173 & \\
\hline
\end{tabular}

\section{Factors relationship:}


A relationship between factor- 1 and factor -2 and between factor -1 and factor- 3 are realized (Fig.-5). These figures clarify that the variables are affected mainly by one factor and are weak $(<0.5)$ on the other. Some variables like K-feldspar and metamorphic rock fragments factor loading are distributed on factor -1 and factor- 2 (Fig.-5). Altered feldspar and carbonate rock fragments are distributed on factor-2 and factor-3 (Fig.-5) while the chert shows a high factor loading on the three different factors of the three sections. This result probably reflects the different source locations of the chert. Heavy minerals also show a high factor loading on factor-1(Al-Khazer section), on factor -2 (Ain Sifni section) and on factor -3 (Bastora section). These distributions probably explain the different solubilities of heavy minerals that are affected by the type of heavy mineral, erosion, diagensis and metamorphism.

Principally, the three factors and their factor loading point out acidic igneous rock of the source rocks which are affected by partial metamorphism. This fact is reflected by factor loading of igneous and metamorphic quartz, mica group \& chlorite and potasic sodic feldspar. The mechanical erosion of sedimentary rocks (carbonate and clastic rock fragment) was different in the studied sections and this is clear on the factor loading of these variables in sections. All these results indicate that the studied sandstones of Injana Formation were texturally immature.

\section{CONCLUSIONS}

The modal analysis of the studied sandstones of Injana Formation reflected a presence of several mineral and rock fragments. In addition to carbonate, iron oxide, clay and silicate cement. Accordingly, the sandstones are situated on feldspathic litharenite and on recycled orogen-dissected arc

The diagenitic process embraces compaction, cementation, replacement, alteration and recrystalization.

Factor analysis results clarify the presence of three factors these are; factor of diagensis, factor of degree of metamorphism and factor of mechanical erosion. The petrography and factor analysis results indicated that the sandstones of Injana Formation were texturally immature.
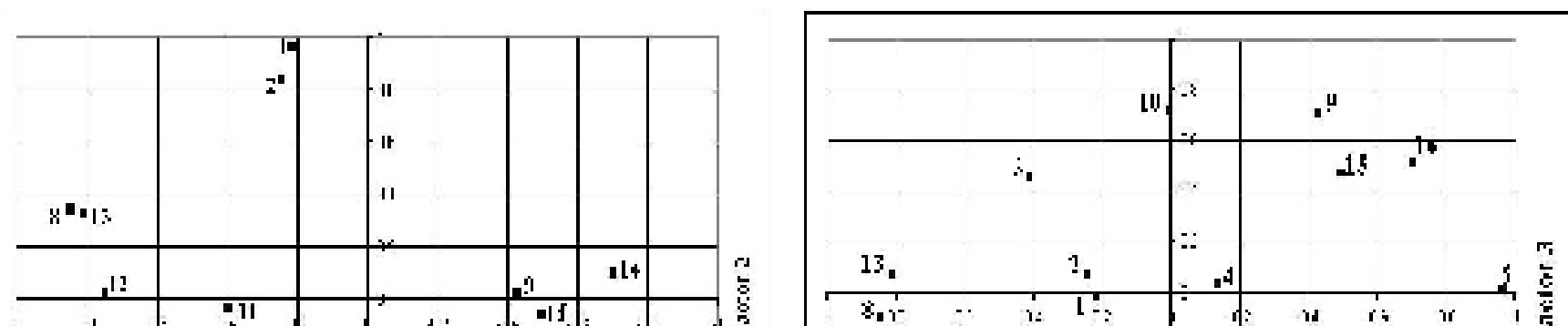
21 Iraqi Journal of Earth Sciences- Vol. 8- No 1- May- 2008 


\section{REFERENCES}

Adams, W.L., 1964: Diagenetic aspects of Lower Morrowan Pennsylvanian sandstones Northwestern Oklahoma, A.A.P.G. Bulletin, Vol. 48, pp. 1568-1580.

Al- Banna, N. Y., 1982: Sedimentological study of Upper Fars Formation in selected area -North Iraq. Unpublished M. Sc. thesis, University of Mosul, Iraq, 177P.

Aswad, K.J., Al-Yozbaky, K. T. and Hermiz, S.A., 2005: Factors controlling the mineralogy and chemical distributions in the Safra Member (Upper Maastrichtian), Western Desert -Iraq. Raf. Journal. Sci: Vol. 16, No.2, Geology Special Issue pp.43-56.

Bellen, R.C., Dunnington, H. V., Wetzel, R. and Morton, D. M., 1959: Lexique Stratigraphique International Asia, Fascicule, 10a, Iraq. Centeral National deal Recherches Scientifique, Paris, 333p.

Buday, T. and Jassim, S., 1987: The Regional Geology of Iraq (tectonism and magmatism). D.G. of Geol. Sur. and Min. Inv., Baghdad, Iraq, 322p.

De Ros, L.F., Morad, S. and Paim, P. S. G., 1994: The role of detrital composition and climate on the diagenetic evolution of continental molasses: Evidence from the Cambro-Ordovician Guaritas Sequence, Southern Brazil. Sedimentary Geology, Vol.92, pp.197-228.

Ingersoll, R.V., Bbullard, T. F., Ford, R. L.,Grimm, J. P., Pickle, J. D. and Sares, S. W., 1984: The effect of grain size on detrital modes: A test of Gazzi-Dickinson point counting method. Jour. Sed. petrology, Vol.54, pp.103-116.

Dickinson, W.R., Beard, L.S., Brakenridge, G.R., Erjavec, J.L., Ferguson, R.C., Inman, K.F., Knepp, R.A., Lindberg, F.A. and Ryberg, P.T., 1983: Provenance of North American Phanerozoic sandstones in relation to tectonic setting. Geol. Soc. America Bull., Vol.94, pp.222-235.

Dypvik, H. and Nilsen, O., 2002: Rift vally sedimentation and diagenesis, Tanzanian Examples-A review, South Africa Journal of Geology, Vol.105, pp.93-106.

Folk, R. L. 1974: Petrology of Sedimentary Rocks, Hemphill Publishing Comp., Texas, $182 p$.

Joo, Y.J., Lee, Y. I. and Hasada, K., 2007: Provenance of Jurassic accretionary complex :Mino terrane, inner zone of south-west Japan-implications for palaeogeography of eastern Asia. Sedimentology, Vol.54, pp. 515-543.

McBride, E.F. 1963: A classification of common sandstones. Jour. of Sed. Petrology, Vol.33, pp.664-669.

McBride, E. F., Picard, M. D. and Milliken, K. L. 2003: Calcite-cemented concretions in Cretaceous sandstone, Wyoming and Utah, U.S.A., Jour. Sed. Research., Vol.70, pp.462-483.

Morad, S., Marfil, R. and Andres de lapena, J., 1989: Diagenetic K-feldspar pseudomorphs in the Triassic Buntsandstein sandstones of the I'berian range, Spain. Sedimentology, Vol. 36, pp.635-650.

Rossi, C., Marfil, R., Ramseyer, K. and Permanyer, A., 2001: Facies-related diagenesis and multiphase siderite cementation and dissolution in the reservoir sandstones of the Khatatba Formation, Egypt's Western Desert. Jour. Sed. Research., Vol.71, pp.459-472. 

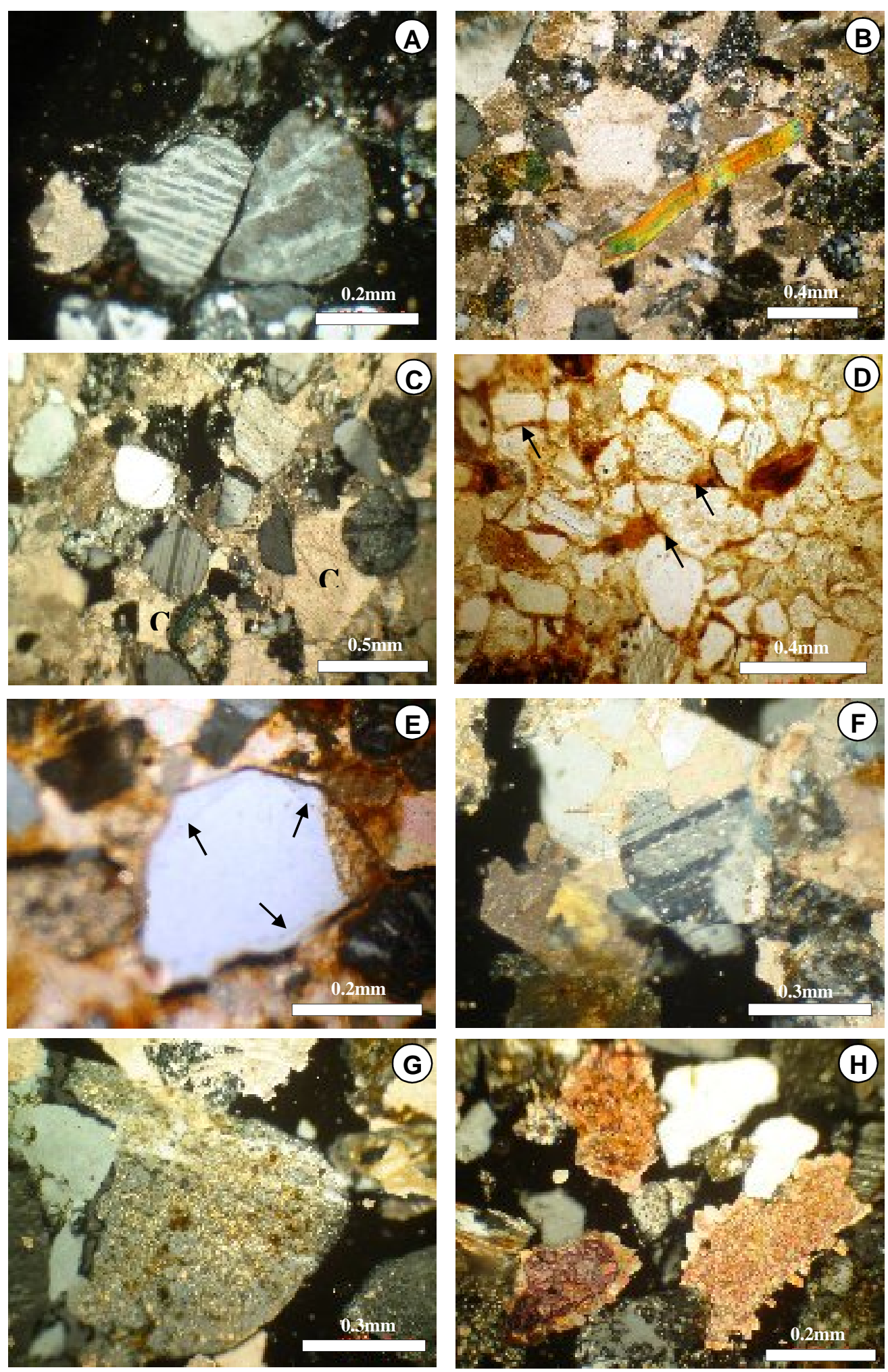

Plate 1: (A) Point \& linear contact, (B) Low degree of curvature of mica grain, (C) Carbonate cement and blocky spary calcite, (D) Thin film of clay and iron oxide cements, (E) Silicate cement, (F) Quartz \& plagioclase are partly replaced by calcite, $(\mathrm{G})$ Alteration of orthoclase to clay minerals, $(\mathrm{H})$ Recrystalliztion of micritic grains to microspar. 